\section{Efficacy and Selectivity of Promising Herbicides for Common Groundsel Control in Newly Established Strawberry}

\author{
Rodrigo Figueroa ${ }^{1}$, \\ Douglas Doohan ${ }^{2}$, and \\ John Cardina ${ }^{2}$
}

AdDitional InDEX wORDs. Senecio vulgaris, Fragaria $\times$ ananassa, sulfentrazone, weed control, herbicide

Summary. Common groundsel (Senecio vulgaris) is an increasingly important weed in strawberries (Fragaria $x$ ananassa), a crop in which open space within and between rows is susceptible to infestations. Cultivation, hand hoeing, and registered herbicide are only partially effective in controlling common groundsel, and tolerance or resistance to herbicides is common in this species. Field and greenhouse studies were conducted to identify and select herbicides for controlling common groundsel in newly planted strawberries. Herbicides applied to strawberries within 1 week after planting in 2000 were: terbacil and simazine alone and tank mixed with napropamide; pendimethalin, dimethenamid, metolachlor, ethofumesate and sulfentrazone. Based on selectivity and efficacy observed in this preliminary experiment, sulfentrazone and flumiclorac were selected for further evaluation in 2001 and 2002. Strawberry tolerance of sulfentrazone

${ }^{1}$ Assistant Professor, School of Agriculture and Forestry, Pontificia Universidad Católica de Chile; to whom reprint requests should be addressed; e-mail: rfe@uc.cl

${ }^{2}$ Associate Professor, Dept. of Horticulture and Crop Science, The Ohio State University, Wooster, OH 44691.

Salaries and research support provided in part by Pontificia Universidad Católica de Chile and state and federal funds appropriated to the Ohio Agricultural Research and Development Center, The Ohio State University.

We would like to thank Tim Koch for his support with herbicide applications and evaluations; Bert Bishop for his valuable guidance with statistical analysis; John Elliott for crop management, especially during frost control periods; and Cathy Herms and Joel Felix for reviewing this manuscript. and flumiclorac $1,3,6$, and 18 weeks after application (WAA) was similar to that of the registered herbicides terbacil and napropamide, but injury was greater than in hand weeded plots. Plants sprayed with $300 \mathrm{~g} \cdot \mathrm{ha}^{-1}$ $(4.3 \mathrm{oz} / \mathrm{acre})$ sulfentrazone produced yields similar to terbacil treated plants, but with less plant stunting. Tolerance of newly planted 'Allstar' and 'Jewel' was affected by the interaction of soil $\mathrm{pH}$ and sulfentrazone rate. Plant stunting 3 WAA increased with sulfentrazone rate, reaching 68 and $61 \%$ in 'Allstar' and 'Jewel', respectively, with the highest rate [400 g.ha $\left.{ }^{-1}(5.7 \mathrm{oz} / \mathrm{acre})\right]$ and high soil pH (7). 'Allstar' grown in low $\mathrm{pH}(5)$ and treated with sulfentrazone (400 g.ha ${ }^{-1}$ ) showed only $8 \%$ stunting, whereas 'Jewel' was not stunted 3 WAA at the same rate and $\mathrm{pH}$. Both cultivars recovered ( $50 \%$ less stunting) from the severe injury observed when sulfentrazone was applied to high $\mathrm{pH}$ soils. However, at low $\mathrm{pH}$ both cultivars were stunted more at 6 WAA than at 3 WAA. Plant diameter for both cultivars was $25 \%$ higher when they were grown in the lower soil $\mathrm{pH}$. Fruit yield was not affected by the sulfentrazone rates evaluated ( 0 to $\left.400 \mathrm{~g} \cdot \mathrm{ha}^{-1}\right)$. Sulfentrazone was active at four stages of common groundsel growth: preemergence (PRE), cotyledon (COT), early post (EPOST) seedlings at the four-leaf stage, and late post (LPOST) seedlings at the 10-leaf stage. The calculated $50 \%$ growth reduction $\left(\mathrm{GR}_{50}\right)$ value for PRE and COT stages was $50 \mathrm{~g} \cdot \mathrm{ha}^{-1}$ $(0.7 \mathrm{oz} /$ acre $)$, whereas the $\mathrm{GR}_{50}$ for EPOST and LPOST stages was 100 $\mathrm{g} \cdot \mathrm{ha}^{-1}(1.4 \mathrm{oz} / \mathrm{acre})$. Sulfentrazone controlled common groundsel when applied PRE and COT, but at EPOST and LPOST stages sulfentrazone did not provide complete control, although plant height was reduced $80 \%$ to $90 \%$ compared to untreated plants. Results indicated that common groundsel is controlled in the field with 150 and $300 \mathrm{~g} \cdot \mathrm{ha}^{-1}$ (2.1 and $4.3 \mathrm{oz} / \mathrm{acre}$ ) of sulfentrazone applied before seedling emergence. The least strawberry injury occurred when sulfentrazone was applied immediately after transplanting at $\mathbf{1 5 0}$ and $\mathbf{3 0 0}$ $\mathrm{g} \cdot \mathrm{ha}^{-1}$, although crop tolerance was reduced under conditions of high soil $\mathrm{pH}(>6.5)$ and varied with cultivar.

$\mathrm{F}$ or strawberry growers using the matted-row production system, weed competition during the first year of plant establishment is a major problem. Uncontrolled growth of weeds during the establishment year can reduce strawberry yield $90 \%$ (Pritts and Kelly, 2001). One month of competition following planting reduced yield $20 \%$, and 2 months of competition reduced yield $65 \%$. Soil fumigants, herbicides, cultivation, and weeding by hand are used by most growers to control annual weeds (Funt et al., 1985). Methyl bromide is applied on roughly $75 \%$ of the strawberry acreage in the U.S. and is especially critical in the raised-bed plasticulture system used on the majority of farms (Poling, 1993). Fumigants have played a major role in achieving increased yields [U.S. Dept. of Agriculture (USDA), 2001 ]; however, methyl bromide is to be phased out by 2005 , creating a major gap in weed control and pest management (United Nations Environment Programme, 2000) for many growers. Herbicides are applied to only $39 \%$ of the strawberry acreage in the U.S. The main products applied are paraquat and napropamide, which are used on 19\% and $13 \%$ of the total area (respectively), followed by simazine and terbacil, with $6 \%$ each (USDA, 2001).

Common groundsel is one of the most frequent species encountered in strawberries (Clay, 1985; United Kingdom Ministry of Agriculture, Fisheries and Food, 1977). Common groundsel is a prolific seeder and is self-pollinated (Haskell, 1953). Its airborne seeds have an obligate light requirement for germination but otherwise exhibit little seed dormancy. Common groundsel produces multiple life cycles per year, allowing seeds to increase rapidly in the soil seed bank (Cussans, 1966; Nielsen and Pinnerup, 1982). The open space within and between strawberry rows provides an excellent niche for the establishment of this species. Cultivation, hand hoeing and applications of registered herbicide are only partially effective in controlling common groundsel. Terbacil and simazine (at $150 \mathrm{~g} \cdot \mathrm{ha}^{-1}$ ) alone or tank mixed with napropamide $\left[4 \mathrm{~kg} \cdot \mathrm{ha}^{-1}\right.$ $(3.6 \mathrm{lb} /$ acre $)]$, provided less than $60 \%$ control (Figueroa et al., 2002), although common groundsel is listed as a sensitive species on the label of napropamide. Resistance to terbacil and simazine has been reported in this species (Bouverat-Bernier and Gallotte, 1989; Ferriere, 1986; Mallory-Smith, 1998; Netland et al., 1996; Radosevich and Appleby, 1973; Radosevich and Devilliers, 1976; Ryan, 1970; Vekshin et al., 1978), and may be a factor in the 
poor control observed with terbacil in our preliminary research.

Several herbicides have recently been identified by the Interregional Research Project 4 (IR4) as potentially useful on strawberry, including sulfentrazone, flumioxazin, pendimethalin, and metolachlor (USDA, 2003). This research was conducted to confirm selectivity of these and additional herbicides on strawberry and their efficacy on common groundsel.

\section{Materials and methods}

Herbicide efFICACY studies. Crop tolerance and herbicide performance were evaluated during 2000, 2001 , and 2002 on a strawberry farm near Wooster, Ohio [long. $81^{\circ} 58^{\prime} \mathrm{W}$, lat. $40^{\circ} 45^{\prime} \mathrm{N}$, elevation $300 \mathrm{~m}(984$ $\mathrm{ft})$. The soil type was a Wooster silt loam (Oxyaquic Fragiudalf) with organic matter of $2.6 \%, 1.0 \%$, and $2.8 \%$ and $\mathrm{pH}$ values of $5.5,5.8$, and 6.0 , for the 3 years, respectively. Wheat (Triticum spp.) was harvested from all fields in July, followed by methyl bromide/chloropicrin $(67 \% / 33 \%)$ fumigation at a rate of $393 \mathrm{~kg} \cdot \mathrm{ha}^{-1}$ $(350.6 \mathrm{lb} /$ acre $)$ in September of the year before planting. Soil preparation consisted of chisel plowing and disking followed by two passes with a field cultivator in May. 'Jewel' strawberry plants (Nourse Farms, South Deerfield, Mass.) were established in a matted row, perennial production system with spacings of $45 \mathrm{~cm}$ within rows and 96 $\mathrm{cm}$ between rows $(17.7 \times 37.8$ inches $)$. Five cultivations and two hand-hoe weedings were carried out during the summer, 2 or 3 weeks apart. Fertilizer was applied at a rate of $336 \mathrm{~kg} \cdot \mathrm{ha}^{-1}$ (299.8 lb/acre) (9N-10.1P-24.9K) before planting plus a top dressing of $\mathrm{N}$ at $33 \mathrm{~kg} \cdot \mathrm{ha}^{-1}(29.4 \mathrm{lb} /$ acre $)$ during the first summer. For the fruiting year, $\mathrm{N}\left[90 \mathrm{~kg} \cdot \mathrm{ha}^{-1}(80.3 \mathrm{lb} /\right.$ acre $\left.)\right]$ was added after plant renovation in July. All fields were irrigated as needed using a $60 \times 60$ solid-set sprinkler irrigation system $\left[2.5\right.$ to $3.0 \mathrm{~mm} \cdot \mathrm{h}^{-1}(0.10$ to 0.12 inch/h)]. Flower buds were removed during the establishment year within 3 to 4 weeks after planting (WAP).

Herbicides were applied within a week of planting, at the end of May each year. Treatments were applied with a carbon dioxide-pressurized $[276 \mathrm{kPa}$ (40 psi)] backpack sprayer equipped with TJ-8002VS flat fan nozzles (Spraying Systems Co., Wheaton, Ill.) delivering a water volume of $187 \mathrm{~L} \cdot \mathrm{ha}^{-1}$
(20.0 gal/acre). All treatments were replicated 4 times in a randomized complete-block design. Plots $[5 \times 2$ $\mathrm{m}(16.4 \times 6.6 \mathrm{ft})]$ consisted of two rows with 10 plants per row. Rows were sprayed with a $2-\mathrm{m}$-wide boom. The treated area extended $50 \mathrm{~cm}$ (19.7 inches) beyond the outside edge of each strawberry row. At the time of herbicide application strawberry plants were actively growing and had two or three new leaves. Weeds had not emerged. Untreated control plots (hand weeded) were included in all the experiments.

A preliminary experiment carried out during 2000 included the herbicides most commonly used in strawberries in the midwestern U.S.: terbacil and simazine [both at 75 and $150 \mathrm{~g} \cdot \mathrm{ha}^{-1}$ (1.1 and $2.1 \mathrm{oz} /$ acre $\left.)\right]$ alone and tank mixed with napropamide at $4 \mathrm{~kg} \cdot \mathrm{ha}^{-1}$. Other herbicides included those identified through a database search of the literature as those that might have potential for use in strawberries: pendimethalin and metolachlor both at 1.75 and $3.5 \mathrm{~kg} \cdot \mathrm{ha}^{-1}$ (1.561 and $3.12 \mathrm{lb} /$ acre), dimethenamid at 1.25 and $2.5 \mathrm{~kg} \cdot \mathrm{ha}^{-1}$ (1.115 and 2.23 $\mathrm{lb} /$ acre), ethofumesate at $0.9 \mathrm{~kg} \cdot \mathrm{ha}^{-1}$ $(0.80 \mathrm{lb} /$ acre $)$ and sulfentrazone at $420 \mathrm{~g} \cdot \mathrm{ha}^{-1}$ ( $\left.6.0 \mathrm{oz} / \mathrm{acre}\right)$. These treatments were evaluated visually 3 weeks after application (WAA). Foliar injury was evaluated, using a scale of 0 to 5 , in which $0=$ no damage, $1=$ leaf chlorosis $<50 \%, 2=$ leaf chlorosis $>50 \%$ and petioles twisting, $3=$ leaf chlorosis $>50 \%$ and slight leaf necrosis restricted to the margins, $4=$ severe leaf necrosis, and $5=$ plant death. Strawberry plant stunting and common groundsel control were also estimated, using a linear scale of 0 to 100 , in which $0=$ no strawberry stunting or no common groundsel control and $100=$ complete stunting and complete control of groundsel. The data were used as a guide to design subsequent trials.

In 2001-02, only three herbicides showing low phytotoxicity in $2000(<0.5 \%$ foliar injury and $<12 \%$ plant stunting 3 WAA) or acceptable activity on groundsel $(>80 \%)$ were assessed further: terbacil, napropamide and sulfentrazone. Flumiclorac was also evaluated [33 and $45 \mathrm{~g} \cdot \mathrm{ha}^{-1}(0.5$ and $0.6 \mathrm{oz} /$ acre $)]$ based upon its prioritization by the IR4 as a herbicide with potential utility on strawberry. Crop tolerance was evaluated 1 and 3 WAA by visually estimating the percent plant stunting and chlorosis, where 0 = no visible damage and $100=$ death of strawberry plants. Six WAA stolons were counted from the five central plants in each plot and the diameter of the crop canopy was measured as described by Manning and Fennimore (2001). At 18 WAA crop tolerance was reassessed, by measuring plant height and percent of ground covered by the strawberry canopy. Percent groundsel control was also estimated at this time. In June 2002 and 2003, berries were harvested by hand on three dates from plants in the central $1 \mathrm{~m}(3.3 \mathrm{ft})$ of a randomly selected row in each plot. Fully red and ripened fruits were classified as marketable, and partially red or rotten fruits as unmarketable.

All data were subjected to the SAS GLM procedure (SAS Institute, Cary, N.C.) using the repeated measurements statement for multiple evaluations of plant stunting and chlorosis within years. Means were separated by Fisher's protected least square differences (LSD) at $P=0.05$ or, when more sensitivity to potential crop damage was needed, at $P=0.1$. Percentage data were arcsine transformed when analysis of variance (ANOVA) assumptions were not fulfilled. Only non-transformed values are presented. Data were combined across years if no year effect or treatment by year interactions occurred.

EFFECT OF SOIL PH ON STRAWBERRY TOLERANCE TO SULFENTRAZONE. Preliminary experiments conducted by the authors indicated that strawberry tolerated sulfentrazone. However, Grey et al. (1997, 2000) reported greater phytotoxicity, water solubility and mobility of sulfentrazone in soils with $\mathrm{pH}>6.5$, and increased availability for uptake by plants. Our preliminary experiments were conducted in soils with $\mathrm{pH}$ ranging from 5.5 to 6 ; therefore, we wanted to elucidate if crop tolerance might be reduced in soils of higher $\mathrm{pH}$. To test this hypothesis, field studies were established at the Ohio Agricultural Research and Development Center at Wooster during 2002 to determine the influence of soil $\mathrm{pH}$ on strawberry tolerance. Three factors (two pH levels, two cultivars, and four sulfentrazone rates) were evaluated in a randomized complete-block design with four replications per treatment. To obtain high pH plots, a $1: 2$ mix of medium-textured silica sand $[0.25-0.5$ $\mathrm{mm}$ (0.010-0.02 inches)] and hydrated lime was added to the soil 1 
week before planting in May 2002 A drop spreader was calibrated to apply a rate of $1 \mathrm{t} \cdot \mathrm{ha}^{-1}(892.2 \mathrm{lb} /$ acre $)$ (Michigan State University Extension, 1995 ). Analysis of soil samples taken 2 months after adding lime confirmed that soil $\mathrm{pH}$ had increased from 6.0 to 6.9. The increase in soil pH $[7.0 \pm 0.2$ $(\mathrm{CV}=0.04 \%)]$ was confirmed in every plot 5 months after adding lime. An immediately adjacent field with a soil $\mathrm{pH}$ of 5 was used for the low $\mathrm{pH}$ field. Strawberry cultivars (Nourse Farms, South Deerfield, Mass.) 'Jewel' and 'Allstar' were planted in each main plot during May 2002. Two rows of each cultivar were assigned at random to four of eight sulfentrazone-treated plots within each block. Each plot contained two rows of strawberry with 10 plants each. Nutrients were applied after planting [ $\mathrm{N}$ at $40 \mathrm{~kg} \cdot \mathrm{ha}^{-1}(35.7$ $\mathrm{lb} /$ acre) ] and early fall (September) as potassium nitrate. Sulfentrazone was applied at $0,100,200$, and $400 \mathrm{~g} \cdot \mathrm{ha}^{-1}$ $(0,1.4,2.9$, and $5.7 \mathrm{oz} /$ acre $)$, one WAP. All plots were hand weeded every other week. Irrigation was provided through central pivots, as needed during the summer. Methods previously described were used for estimating percent stunting and chlorosis, number of stolons, plant height and diameter ( 3 and 6 WAA) and fruit harvest.

ANOVA of data was carried out using SAS GLM procedures testing for significance of main effect and interactions. Because it was not possible to randomly replicate the $\mathrm{pH}$ effect, inferences to $\mathrm{pH}$ are limited. When significant differences occurred orthogonal contrasts were used for mean separation at the $5 \%$ significance level.

SulfeNTRAZONE DOSE RESPONSE. A greenhouse experiment was performed to determine the response of common groundsel at various growth stages to a range of sulfentrazone rates. On 17 Apr. 2003, common groundsel was seeded in $110-\mathrm{mm}$ (4.3 inches) plastic pots containing a Pro-Mix BX (Premier Horticulture Inc., Red Hill, Pa.) that consisted of: Canadian sphagnum peat moss $(75 \%$ to $85 \%$ volume), perlite, vermiculite, dolomitic and calcitic limestone and a wetting agent. Seeded pots were placed in a greenhouse mist room $[25 \pm 1$ $\left.{ }^{\circ} \mathrm{C}\left(77.0 \pm 1.8^{\circ} \mathrm{F}\right)\right]$ set to mist every $10 \mathrm{~min}$ for $10 \mathrm{~s}$ intervals. Plants were fertilized once a week with $200 \mathrm{mg} \cdot \mathrm{L}^{-1}$ (ppm) of a $20 \mathrm{~N}-8.7 \mathrm{P}-16.6 \mathrm{~K}$ solution. Seeds were planted 4 times, $10 \mathrm{~d}$ apart, to achieve four common groundsel seedling stages at herbicide application: PRE (preemergence), COT (cotyledon stage), EPOST (early post, seedlings with four fully expanded leaves) and LPOST (late post, seedlings with 10 fully expanded leaves). After 1 week in the mist room, plants were moved outdoors to benches under direct sun light to promote plant hardening and leaf cuticle development. The shortest interval between moving seedlings outside and herbicide application was 1 week for plants at COT.

A split plot design was used, with groundsel seedling stages as the main plot and sulfentrazone rate $[0,25,50$, 100,200 , and $400 \mathrm{~g} \cdot \mathrm{ha}^{-1}(0,0.4,0.7$, $1.4,2.9$, and $5.7 \mathrm{oz} /$ acre) $]$ as the subplot. Four replications were used. All groundsel seedling stages were sprayed at the same time. A compressed-air laboratory sprayer equipped with TJ-8002VS flat fan nozzles (Spraying Systems Co.) calibrated to deliver 187 $\mathrm{L} \cdot \mathrm{ha}^{-1}$ at a pressure of $276 \mathrm{kPa}$ was used. Groundsel response to sulfentrazone was estimated by measuring plant height 3 WAA. The entire experiment was repeated.

ANOVA was conducted using SAS GLM procedure, including analysis of interactions between main factors (groundsel seedling stages, sulfentrazone rates and experiment replication).
Seedling height 3 WAA of all sulfentrazone treated groundsel plants was converted to percent of the untreated control. Each groundsel seedling stage was regressed on sulfentrazone rate using the SAS NLIN procedure. This procedure produced the parameters needed to fit a log-logistic function (Seedfeldt et al., 1995) and obtain the rate-response curves defined by the equation:

$\%$ of control height $=\mathrm{C}+\frac{(\mathrm{D}-\mathrm{C})}{\left[\mathrm{l}+\left(\mathrm{x} / \mathrm{GR}_{50}\right)^{\mathrm{b}}\right]}$

[Eq. 1]

where $\mathrm{C}=$ the mean response of the highest dose; $\mathrm{D}=$ mean response of the untreated; $b=$ slope $; x=$ sulfentrazone rate; and $\mathrm{GR}_{50}=50 \%$ growth reduction.

\section{Results and discussion}

Herbicide efFicacy studies. Strawberry plants tolerated, or were only slightly injured, by 11 of 16 herbicide treatments evaluated in 2000 (Table 1). Three WAA the size of strawberry plants in plots treated with terbacil, simazine, dimethenamid, metolachlor and sulfentrazone was similar to plants in the untreated control. Strawberry plants in plots treated with napropamide $\left(4 \mathrm{~kg} \cdot \mathrm{ha}^{-1}\right)$ tank-mixed with either terbacil $(75$ $\left.\mathrm{g} \cdot \mathrm{ha}^{-1}\right)$ or simazine $\left(150 \mathrm{~g} \cdot \mathrm{ha}^{-1}\right)$, pen-

Table 1. Strawberry injury and common groundsel control 3 weeks after application (WAA) in response to herbicides applied the day of transplanting in 2000.

\begin{tabular}{|c|c|c|c|c|}
\hline $\begin{array}{l}\text { Herbicide } \\
\text { treatment }\end{array}$ & $\begin{array}{c}\text { Rate } \\
\left(\mathrm{kg} \cdot \mathrm{ha}^{-1} \text { a.i. }\right)^{\mathrm{z}}\end{array}$ & $\begin{array}{c}\text { Foliar } \\
\text { injury }^{y}\end{array}$ & $\begin{array}{c}\text { Crop } \\
\text { stunting }\end{array}$ & $\begin{array}{c}\text { Groundsel } \\
\text { control }\end{array}$ \\
\hline Control & --- & 0 & 0 & 0 \\
\hline Terbacil & 0.075 & 0.1 & 9 & 53 \\
\hline Terbacil & 0.15 & 0.4 & 9 & 45 \\
\hline Simazine & 0.075 & 0.3 & 6 & 46 \\
\hline Simazine & 0.15 & 1.0 & 11 & 63 \\
\hline Terbacil + napropamide & $0.075+4.0$ & 0.5 & 12 & 38 \\
\hline Terbacil + napropamide & $0.15+4.0$ & 0.1 & 8 & 58 \\
\hline Simazine + napropamide & $0.075+4.0$ & 0.4 & 9 & 70 \\
\hline Simazine + napropamide & $0.15+4.0$ & 0.8 & 16 & 65 \\
\hline Pendimethalin & 1.75 & 2.3 & 23 & 64 \\
\hline Pendimethalin & 3.5 & 3.3 & 33 & 76 \\
\hline Dimethenamid & 1.25 & 0.6 & 5 & 50 \\
\hline Dimethenamid & 2.5 & 0.5 & 6 & 63 \\
\hline Metolachlor & 1.75 & 0.8 & 6 & 43 \\
\hline Metolachlor & 3.5 & 1.6 & 9 & 78 \\
\hline Ethofumesate & 0.9 & 1.5 & 12 & 64 \\
\hline Sulfentrazone & 0.42 & 1.2 & 11 & 100 \\
\hline $\operatorname{LSD}(P \leq 0.05)^{x}$ & & 1 & 12 & 26 \\
\hline
\end{tabular}

${ }^{\mathrm{z}} 1.000 \mathrm{~kg} \cdot \mathrm{ha}^{-1}=0.8922 \mathrm{lb} /$ acre

'Foliar injury index: $0=$ no damage; $1=$ leaf chlorosis $<50 \% ; 2=$ leaf chlorosis $>50 \%$ and petioles twisting; $3=$ leaf chlorosis $>50 \%$ and slight leaf necrosis restricted to the margin; $4=$ severe leaf necrosis; and $5=$ plant death. ${ }^{{ }}$LSD $=$least significant difference. 
dimethalin, and ethofumesate were stunted. Pendimethalin caused severe stunting $(>20 \%)$ and foliar injury (3.3). Strawberry foliar injury was also significant in plots treated with

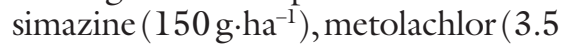
$\left.\mathrm{kg} \cdot \mathrm{ha}^{-1}\right)$, ethofumesate, and sulfentrazone. However, with the exception of ethofumesate and metolachlor at $3.5 \mathrm{~kg} \cdot \mathrm{ha}^{-1}$, plants in these plots were not injured as much as those in plots treated with pendimethalin.

Every herbicide treatment provided some control of common groundsel (Table 1). Treatments containing napropamide, the only herbicide recommended for control of the species, provided $38 \%$ to $70 \%$ control 3 WAA. Treatments of terbacil tank-mixed with napropamide were not better than terbacil alone. Napropamide did when used in combination with simazine at $75 \mathrm{~g} \cdot \mathrm{ha}^{-1}$ compared to this rate of simazine alone. Pendimethalin and dimethenamid controlled $63 \%$ and $76 \%$ of common groundsel at the highest rates applied, 3.5 and $2.5 \mathrm{~kg} \cdot \mathrm{ha}^{-1}$, respectively. Common groundsel control increased from $43 \%$ to $78 \%$ when the rate of metolachlor was increased from 1.75 to $3.5 \mathrm{~kg} \cdot \mathrm{ha}^{-1}$. The best common groundsel control (100\%) was achieved only in plots sprayed with sulfentrazone at $420 \mathrm{~g} \cdot \mathrm{ha}^{-1}$. Because sulfentrazone provided excellent control of common groundsel and caused minimal crop stunting 3 WAA $(<12 \%)$ with rapid recovery, it was selected as the most promising treatment for subsequent trials. Fruits were not harvested from this study because a late season storm caused severe soil erosion that created improve common groundsel control

gullies running through the plots.

Strawberry and common groundsel response to herbicides tested in 2001 and in 2002 did not differ between years; therefore, data presented are the average values after combining both growing seasons (Table 2). One WAA, chlorosis was observed on strawberry plants treated with herbicides; however, this was only significant in plots treated with terbacil at $150 \mathrm{~g} \cdot \mathrm{ha}^{-1}$ and terbacil $300 \mathrm{~g} \cdot \mathrm{ha}^{-1}$ tank-mixed with napropamide. Chlorosis in herbicide treated plots declined rapidly and by 3 WAA was no longer significant (data not reported). Stunting of herbicide treated strawberry plants was readily apparent 1 WAA, ranging from $13 \%$ with sulfentrazone at $150 \mathrm{~g} \cdot \mathrm{ha}^{-1}$ and with terbacil tank-mixed with napropamide $\left(150 \mathrm{~g} \cdot \mathrm{ha}^{-1}+4 \mathrm{~kg} \cdot \mathrm{ha}^{-1}\right)$ to $34 \%$ with terbacil applied alone at $300 \mathrm{~g} \cdot \mathrm{ha}^{-1}$. Plants treated with terbacil at $150 \mathrm{~g} \cdot \mathrm{ha}^{-1}$ remained severely stunted 3 WAA. These data suggest a safening effect when napropamide was tank-mixed with terbacil. We have also observed this effect in other studies (Figueroa, 2003). The high rate of sulfentrazone stunted strawberry plants at 1 and 3 WAA, but by 6 WAA stunting was no longer detected for this, or any other treatment, except for flumiclorac. Similarly, Manning and Fennimore (2001) concluded that sulfentrazone $\left[280 \mathrm{~g}^{-h^{-1}}(4.0\right.$ $\mathrm{oz} / \mathrm{acre}$ )] was safe for use immediately after transplanting newly established 'Selva' and 'Camarosa' strawberries. Flumiclorac severely stunted strawberry plants at both rates and stunting persisted beyond 3 WAA.

Strawberry stolons, plant diameter, height, and canopy cover measured

Table 2. Response of newly planted strawberry at 1 and 3 weeks after application (WAA) to herbicides applied immediately after transplanting (data were combined for 2001 and 2002).

\begin{tabular}{|c|c|c|c|c|c|}
\hline \multirow{2}{*}{$\begin{array}{l}\text { Herbicide } \\
\text { treatment }\end{array}$} & \multirow{2}{*}{$\begin{array}{c}\text { Rate } \\
\left(\mathrm{kg} \cdot \mathrm{ha}^{-1} \text { a.i. }\right)^{\mathrm{z}}\end{array}$} & \multirow{2}{*}{$\begin{array}{l}\text { Chlorosis } \\
1 \text { WAA }\end{array}$} & \multicolumn{2}{|c|}{ Stunting } & \multirow{2}{*}{$\begin{array}{c}\text { Fruit yield } \\
\left(\mathrm{kg} \cdot \mathrm{m}^{-2}\right)^{\mathrm{y}}\end{array}$} \\
\hline & & & 1 WAA & 3 WAA & \\
\hline & & $-\cdots$ & $\%$ & -- & \\
\hline Control & --- & 0 & 0 & 0 & 2.46 \\
\hline Terbacil & 0.15 & 14 & 34 & 27 & 2.33 \\
\hline Terbacil + napropamide & $0.15+4.0$ & 5 & 13 & 8 & 2.67 \\
\hline Terbacil + napropamide & $0.30+4.0$ & 17 & 20 & 17 & 2.88 \\
\hline Sulfentrazone & 0.15 & 5 & 13 & 14 & 2.41 \\
\hline Sulfentrazone & 0.30 & 8 & 20 & 20 & 2.61 \\
\hline Flumiclorac & 0.033 & 3 & 19 & 17 & 2.54 \\
\hline Flumiclorac & 0.045 & 13 & 30 & 18 & 2.63 \\
\hline $\operatorname{LSD}(P \leq 0.1)^{\mathrm{x}}$ & & 14 & 18 & 13 & 0.5 \\
\hline
\end{tabular}

at 6 and 18 WAA were not affected by herbicide treatments (data not reported). Failure to determine significant differences within these parameters at 6 WAA suggests that visual estimation of stunting was a more sensitive and reliable indicator of persistent crop injury. Strawberry growth was greatest in plots sprayed with terbacil plus napropamide $\left(300 \mathrm{~g} \cdot \mathrm{ha}^{-1}+4 \mathrm{~kg} \cdot \mathrm{ha}^{-1}\right)$ and lowest in plots sprayed with terbacil alone (150 g.ha- $\left.\mathrm{h}^{-1}\right)$. Fruit yield was significantly reduced in plots treated with terbacil at $150 \mathrm{~g} \cdot \mathrm{ha}^{-1}$ compared to yield in plots treated with the tank-mix of terbacil plus napropamide $(300+4$ $\left.\mathrm{kg} \cdot \mathrm{ha}^{-1}\right)$. With the exception of terbacil at $150 \mathrm{~g} \cdot \mathrm{ha}^{-1}$, fruit yield and quality in herbicide-treated plots was similar to the untreated control.

Few weeds occurred in trials established in 2001 and 2002 during spring and summer of the first year because the fields had been fumigated with methyl bromide the fall prior to planting. Thus, observations on common groundsel control were delayed until late in the growing season (18 WAA), by which time seedlings had emerged in the plots. Sulfentrazone at 150 and $300 \mathrm{~g} \cdot \mathrm{ha}^{-1}$, and terbacil at 150 and $300 \mathrm{~g} \cdot \mathrm{ha}^{-1}$ tank-mixed with napropamide at $4 \mathrm{~kg} \cdot \mathrm{ha}^{-1}$ produced high levels of common groundsel control $(80 \%$ or greater $)$, statistically equivalent to control in hand-weeded plots (Fig. 1). Terbacil at $150 \mathrm{~g} \cdot \mathrm{ha}^{-1}$ and flumiclorac at 30 and $50 \mathrm{~g} \cdot \mathrm{ha}^{-1}$ ( 0.4 and $0.7 \mathrm{oz} /$ acre $)$ provided $50 \%$ to $60 \%$ control.

Soll pH Effects. Strawberry tolerance to sulfentrazone applied immediately after planting was affected by soil $\mathrm{pH}$, cultivar, and rate of sulfentrazone used. ANOVA only indicated interaction between soil $\mathrm{pH}$ and rate of sulfentrazone used. Data are presented in Table 3 comparing the effect of sulfentrazone in strawberry plant stunting across soil $\mathrm{pH}$ levels. Strawberry plants were stunted more at soil pH 7 than at pH 5. 'Jewel' was relatively less sensitive to sulfentrazone, showing plant stunting at soil $\mathrm{pH} 5$ only at the highest rate $\left(400 \mathrm{~g} \cdot \mathrm{ha}^{-1}\right)$ 6 WAA. Visual estimates of stunting indicated that 'Jewel' tolerance 3 WAA was reduced at soil $\mathrm{pH} 7$; however, the cultivar recovered 6 WAA except for those plots treated with sulfentrazone at $400 \mathrm{~g} \cdot \mathrm{ha}^{-1}$. 'Allstar' was more sensitive to sulfentrazone than was 'Jewel' and recovered more slowly. At soil pH 


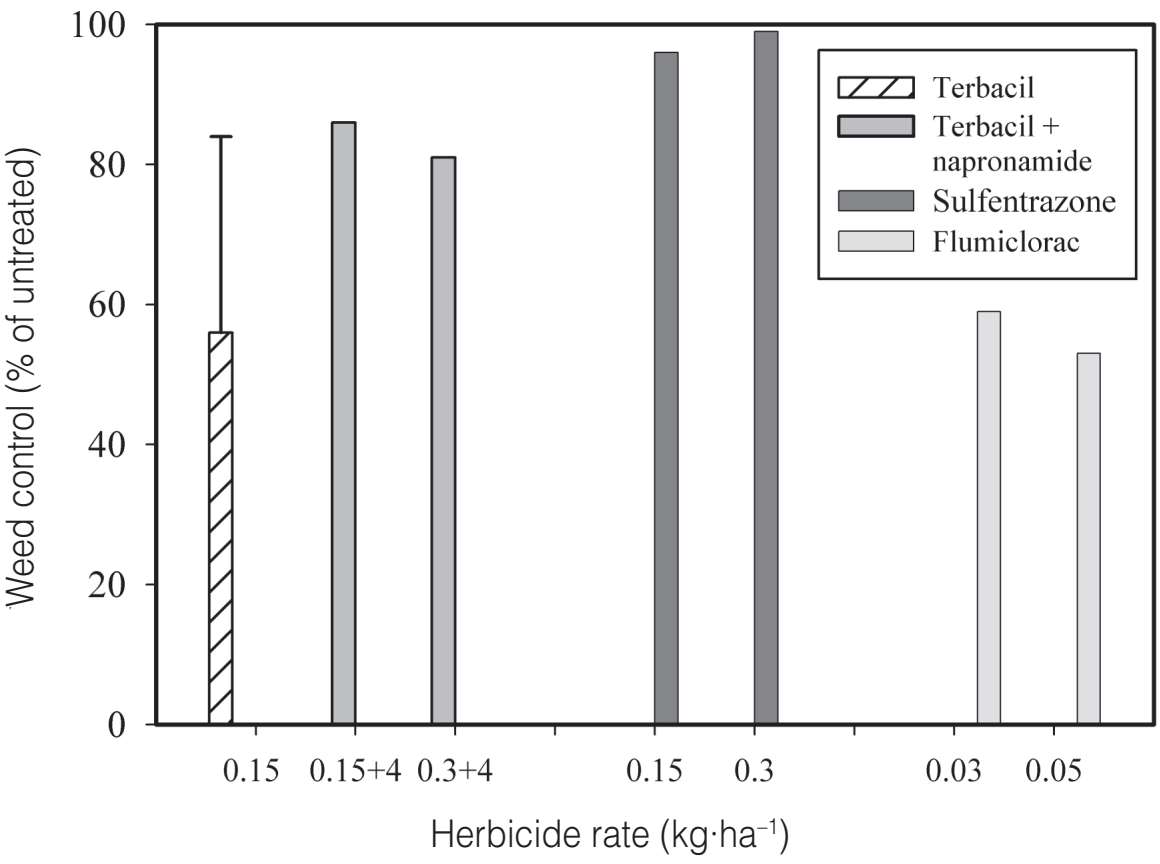

Fig. 1. Control of common groundsel in 2001 and 2002 at 18 weeks after application (WAA) of herbicide treatments to newly transplanted strawberry plants. Error bar represents the least significant difference (LSD, with $P \leq 0.05$ ) to compare treatment response combined by years $\left(1.00 \mathrm{~kg} \cdot \mathrm{ha}^{-1}=0.892 \mathrm{lb} / \mathrm{acre}\right)$.

Table 3. The response of 'Allstar' and 'Jewel' strawberry cultivars to sulfentrazone rates and soil pH levels at 3 and 6 weeks after application (WAA) in 2002. Analysis of variance only indicated interaction between soil $\mathrm{pH}$ and rate of sulfentrazone used.

\begin{tabular}{|c|c|c|c|c|c|c|c|}
\hline \multirow[b]{3}{*}{ Cultivar } & \multirow{3}{*}{$\begin{array}{l}\text { Sulfentrazone } \\
\text { rate } \\
\left(\mathrm{kg} \cdot \mathrm{ha}^{-1} \text { a.i. }\right)^{\mathrm{z}}\end{array}$} & \multicolumn{6}{|c|}{ Plant stunting } \\
\hline & & \multicolumn{2}{|c|}{3 WAA } & \multirow[b]{2}{*}{$P>\mathrm{F}$} & \multicolumn{2}{|c|}{6 WAA } & \multirow[b]{2}{*}{$P>\mathrm{F}$} \\
\hline & & pH5 & pH7 & & pH5 & pH7 & \\
\hline & & $-\cdots---$ & (-.-- & & ---- & - & \\
\hline \multirow[t]{4}{*}{ Allstar } & 0 & 0 & 0 & NS & 0 & 0 & NS \\
\hline & 0.1 & 5 & 25 & * & 11 & 13 & NS \\
\hline & 0.2 & 3 & 38 & ** & 11 & 25 & * \\
\hline & 0.4 & 8 & 68 & $* * *$ & 23 & 50 & ** \\
\hline \multirow[t]{4}{*}{ Jewel } & 0 & 0 & 0 & NS & 0 & 0 & NS \\
\hline & 0.1 & 0 & 11 & NS & 5 & 8 & NS \\
\hline & 0.2 & 1 & 30 & ** & 5 & 13 & NS \\
\hline & 0.4 & 3 & 61 & *** & 18 & 25 & NS \\
\hline \multicolumn{2}{|c|}{ LSD $(P \leq 0.05)^{x}$} & 6 & 28 & & 6 & 20 & \\
\hline
\end{tabular}

5 , only $8 \%$ stunting was observed 3 WAA with $400 \mathrm{~g} \cdot \mathrm{ha}^{-1}$, and by 6 WAA stunting was obvious for all rates of the herbicide. 'Allstar' was severely stunted by sulfentrazone at soil $\mathrm{pH}$ 7,3 WAA. Six WAA some recovery had occurred but stunting was still apparent at 200 and $400 \mathrm{~g} \cdot \mathrm{ha}^{-1}$. Fruit yield was not affected $(P=0.2194)$ by sulfentrazone at the rates tested (100 and $400 \mathrm{~g} \cdot \mathrm{ha}^{-1}$ ). These results are consistent with those of Wehtje et al. (1997) and Grichar et al. (2003) who sulfentrazone at 3 or 6 WAA. However, measurement of this variable at 6 WAA illustrated the greater plant size achieved by 'Jewel' compared to 'Allstar' and the enhanced growth of both cultivars at $\mathrm{pH} 5$ compared to $\mathrm{pH}$ 7 (data not shown). These data suggest that visual estimates provide a better integration of the variables involved in the strawberry plant's response to sulfentrazone than do the individual quantitative measures of plant growth used in this study.

Sulfentrazone DOSE RESPONSE. Common groundsel seedling growth stage at the time of sulfentrazone application influenced subsequent plant growth (Fig. 2). Common groundsel was very sensitive at the PRE and COT stages of growth. Later stages of growth were less sensitive, with LPOST seedlings being slightly more sensitive than EPOST. Common groundsel was completely controlled when sulfentrazone was applied PRE at $25 \mathrm{~g} \cdot \mathrm{ha}^{-1}$, and at $50 \mathrm{~g} \cdot \mathrm{ha}^{-1}$ to seedlings at the COT stage. Seedlings sprayed with sulfentrazone at EPOST and LPOST responded in a curvilinear fashion to rates between 0 and $200 \mathrm{~g} \cdot \mathrm{ha}^{-1}$. At 400 $\mathrm{g} \cdot \mathrm{ha}^{-1}$ EPOST and LPOST seedlings did not die, but achieved only $20 \%$ of the height of untreated plants. These data indicate that sulfentrazone applications should be timed to coincide with groundsel emergence to achieve optimum control. Strawberry growers in Ohio who have used this herbicide under a Section 18 registration have confirmed this observation. Later applications of sulfentrazone corresponding with the EPOST and LPOST timings used in this study are unlikely to provide complete control, but will likely minimize common groundsel growth and reproduction.

Our results showed that common groundsel was readily controlled in the field with applications of sulfentrazone at 150 and $300 \mathrm{~g} \cdot \mathrm{ha}^{-1}$ applied in advance of seedling emergence. Lower rates of the herbicide, 25 and $50 \mathrm{~g} \cdot \mathrm{ha}^{-1}$, respectively, controlled groundsel growing in pots when applied at PRE and at COT stages of growth and may prove effective in future research under field conditions. Later stages of common groundsel seedling growth, EPOST (four-leaf stage) and LPOST (10-leaf stage), were severely injured and subsequent growth suppressed when sulfentrazone was applied to potted plants at 100 to $400 \mathrm{~g} \cdot \mathrm{ha}^{-1}$. This 


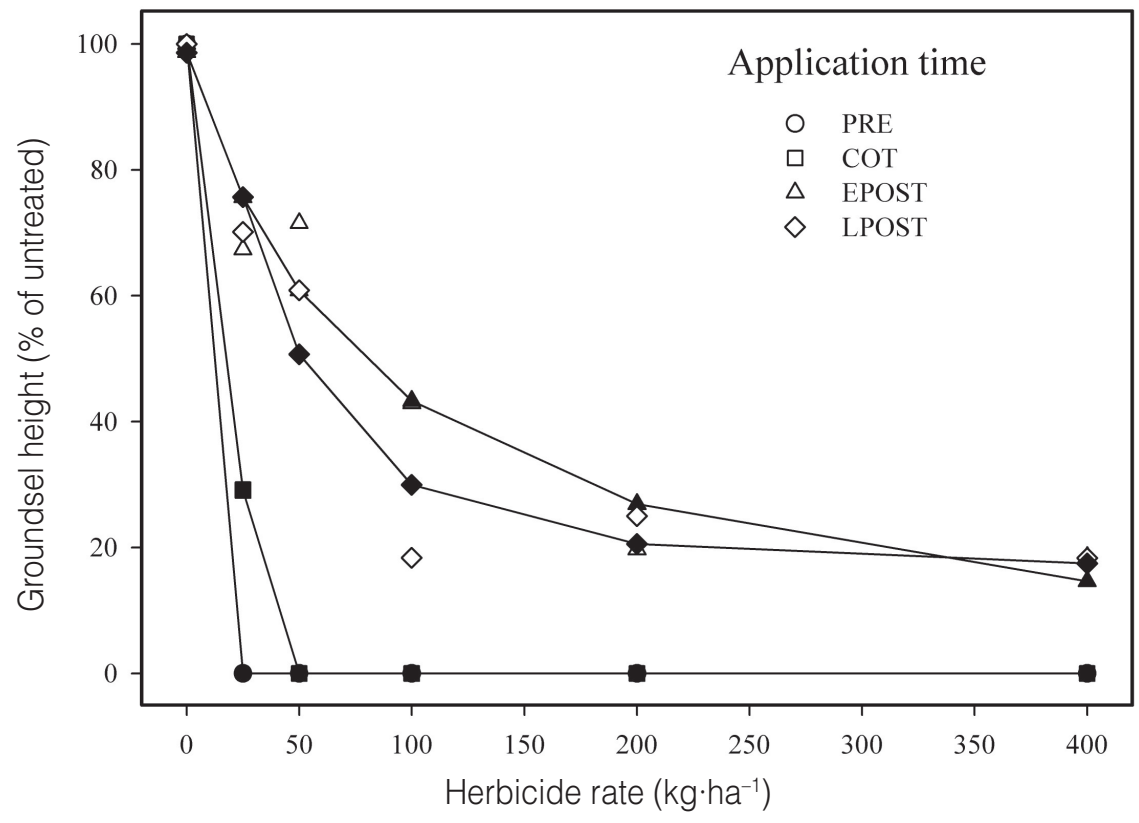

Fig. 2. The effect of common groundsel growth stage and rate of sulfentrazone on common groundsel height 3 weeks after application (WAA). Nonlinear regression (solid symbols) and raw means (outline symbols) were plotted with means combined over experiments for plant height at 3 WAA as a percentage of the untreated control. Stages of common groundsel growth were: preemergence (PRE); cotyledon $(\mathrm{COT})$ = seedlings at the cotyledon stage; early post (EPOST) = seedlings at the four-leaf stage; and late post $($ LPOST $)=$ seedlings at the 10-leaf stage $\left(1.00 \mathrm{~kg} \cdot \mathrm{ha}^{-1}=0.892 \mathrm{lb} /\right.$ acre $)$.

result is in agreement with growers who have observed less than complete control when sulfrentrazone was applied to strawberry in late fall, after common groundsel seedling establishment. Strawberry tolerance of sulfentrazone applied immediately after transplanting at 150 and $300 \mathrm{~g} \cdot \mathrm{ha}^{-1}$ was comparable to that with terbacil, a standard herbicide used for many years. However, we found that tolerance was reduced under conditions of high soil $\mathrm{pH}(>6.5)$ and varied with cultivar.

\section{Literature cited}

Bouverat-Bernier, J.P. and P. Gallotte. 1989. Chemical weed control in peppermint post-planting. Herba Gallica 1:33-37.

Clay, D.V. 1985. Results of a questionnaire on the worst weeds in vine and soft fruits. Proc. European Community Experts' Group p. 157-160.

Cussans, G. 1966. The weed problem. Proc. Brit. Weed Control Conf. 8:884-889.

Ferriere, I. 1986. Resistance phenomena in all areas. Cultivar 92:6-8.

Figueroa, R. 2003. Biology and management of common groundsel (Senecio vulgaris L.) in strawberries. PhD Diss., Ohio State Univ., Wooster.

Figueroa, R., D.J. Doohan, and J. Cardina.
2002. Efficacy and crop tolerance of sulfentrazone on strawberries. Proc. North Central Weed Sci. Soc. 57:152.

Funt, R.C., B.L. Goulart, C.K. Chandler, J.D. Utzinger, M.A. Ellis, R.M. Riedel, R.N. Williams, and M.A. Palmer 1985. Ohio strawberry manual. Ohio State Univ. Coop. Ext. Ser. 43.

Grey, T.L., R.H. Walker, G.R. Wehtje, and H.G. Hancock. 1997. Sulfentrazone adsorption and mobility as affected by soil and $\mathrm{pH}$. Weed Sci. 45:733-738.

Grey, T.L., R.H. Walker, G.R. Wehtje, J. Adams, Jr., F.E. Dayan, J.D. Weete, H.G. Hancock, and O. Kwon. 2000. Behavior of sulfentrazone in ionic exchange resins, electrophoresis gels, and cation-saturated soils. Weed Sci. 48:239-247.

Grichar, W.J., B.A. Besler, and K.D. Brewer. 2003. Purple nutsedge control and potato (Solanum tuberosum) tolerance to sulfentrazone and halosulfuron. Weed Technol. 17:485-490.

Haskell, G. 1953. Adaptation and the breeding system in groundsel. Genetica 26:468-484.

Mallory-Smith, C. 1998. Bromoxynil-resistant common groundsel (Senecio vulgaris). Weed Technol. 12:322-324.

Manning, G.R. and S.A. Fennimore. 2001. Evaluation of low-rate herbicides to supplement methyl bromide alternative fumigants to control weeds in strawberry. Hort Technology
11:603-609.

Michigan State University Extension. 1995. Tri-state fertilizer recommendations for corn, soybeans, wheat and alfalfa. Mich. State Univ. Ext. Bul. E-2567.

Netland, J. et al. 1996. Weed species and frequency of simazine-resistant populations of Poa annua and Senecio vulgaris in nursery stocks imported to Norway or inland-raised. Proc. 2nd Intl. Weed Control Congr. p. 461-468.

Nielsen, H. and S. Pinnerup 1982. Reduced cultivation and weeds. Proc. Swedish Weed Conf. 23:370-384

Poling, E.B. 1993. Strawberry plasticulture in North Carolina: II. Preplant, planting, and postplant considerations for growing 'Chandler' strawberry on black plastic mulch. HortTechnology 3:383-393.

Pritts, M.P. and M.J. Kelly. 2001. Early season weed competition reduces yield of newly planted matted row strawberries. HortScience 36:729-731.

Radosevich, S.R. and A.B. Appleby. 1973. Studies on the mechanism of resistance to simazine in common groundsel. Weed Sci. 21:497-500.

Radosevich, S.R. and O.T. Devilliers. 1976. Studies on the mechanism of s-triazine resistance in common groundsel. Weed Sci. 24:229-232.

Ryan, G.F. 1970. Resistance of common groundsel to simazine and atrazine. Weed Sci. 18:614-616.

Seedfeldt, S., J. Jensen, and P. Fuerst. 1995. Log-logistic analysis of herbicide dose-response relationships. Weed Technol. 9:218-227.

United Kingdom Ministry of Agriculture, Fisheries and Food.1977. Strawberry weed survey, p. 83. In: Review of development work 1976 southwest region. UK Ministry of Agr., Fisheries and Food, London.

United Nations Environment Programme. 2000. The Montreal protocol on substances that deplete the ozone layer. United Nations Environ. Programme, Nairobi, Kenya.

U.S. Dept. of Agriculture. 2001. Agricultural chemical usage, 2000 Vegetable summary. USDA-NASS, Washington, D.C.

U.S. Dept. of Agriculture. 2003. Food use workshop. IR4 Project, Orlando, Fla.

Vekshin, B.S., B. Grigolava, G.P. Pushkina and N.V. Butina. 1978. Results of herbicide testing on plantations of mound lily (Yucca gloriosa) and herbaceous periwinkle (Vinca herbacea). Khimiko Farmatsevticheskii Zhurnal 12:83-86.

Wehtje, G.R., R.H. Walker, T.L. Grey, and H.G. Hancock. 1997. Response of purple (Cyperus rotundus) and yellow nutsedges (C. esculentus) to selective placement of sulfentrazone. Weed Sci. 45:382-387. 